$100(148)$

\title{
PD1 - 3 腎移植患者の高血圧症一その管理上の問題点と対策一
}

新潟大学医学部泌尿器科学講座

齋藤和英

長期生着に影響する因子には大きく分けて免疫学的因子と非免疫学的因子が ある。維持期には後者が大きな役割を担うことが考えられる。その中でも特に 重要之思われる循環器系因子、とくに移植後高血圧症の問題について考えてみ たい。

移植後の高血圧は比較的高率に認められる合併症である。その原因として、 ステロイドホルモン、calcinurine inhibitor等の免疫抑制薬による影響、拒絶反 応・再発性腎炎等による腎障害、移植腎そのものの加齢による影響、腎血管性 高血圧症、除神経されたことによる移植腎の血行動態の特殊性などの多岐にわ たる要因が考えられる。

したがってその病態、治療を考える際には、単に全身血圧をコントロールす ることのみならず、移植腎の血行動態、糸球体高血圧、蛋白尿との関連、糸球 体硬化ならびに間質の線維化についても深い洞察を加えることが必要である。

臨床的には塩分制限がまず重要であるが、薬物療法の選択として、われわれ は腎の血行動態と降圧効果、免疫抑制剤之の相互作用を考慮し、Ca拮抗薬 (amlodipine, manidipine)、 $\alpha$ 遮断薬(doxazocine)、中枢性降圧薬を組み合わせ て初期治療を行っている。

また、定期的にABPM(ambulatory blood pressure monitoring)を行い、血圧日 内変動パターンに合わせた (dipper, non-dipper) 降圧療法を組み立てている。

近年の腎臟病学の進歩により、糸球体高血圧、糸球体過剩濾過が糸球体硬化 を進展させることが明らかになってきている。移植腎もその例外ではなく、わ れわれの最近の研究により、移植腎においては糸球体過剰濾過が高頻度に認め られることが明かとなった。こうした症例では早期から積極的にアンギオテン. シン变換酵素阻害薬 (ACEI)や、アンギオテンシン II受容体拮抗薬 (ARB)を用 いて移植腎血行動態の是正をはかっている。

本稿ではわれわれのデー夕を示しながら移植後高血圧症の成因と治療、その 予後に及ぼす影響について検討を加えたい。 